\title{
COMMUNITY-BASED MANGROVE FORESTS CONSERVATION FOR SUSTAINABLE FISHERIES
}

\author{
Syaiful Eddy ${ }^{*}$, Mohammad Rasyid Ridho ${ }^{2}$, Iskhaq Iskandar ${ }^{2}$, and Andy Mulyana ${ }^{3}$ \\ ${ }^{1}$ Student of Environmental Science Section of Doctorate Program, University of Sriwijaya, Palembang \\ ${ }^{2}$ Faculty of Science, University of Sriwijaya, Inderalaya \\ ${ }^{3}$ Faculty of Agriculture, University of Sriwijaya, Inderalaya \\ *Corresponding author: syaifuleddy@gmail.com
}

\begin{abstract}
The mangrove forests are a type of salt tolerant vegetation, living in tidal zones in tropical and subtropical coastal areas with unique ecosystem that have a strategic function as a connector and counterweight of terrestrial and marine ecosystems. Mangrove forests are a productive ecosystem and they have complex functions, such as physical functions, biological functions and socio-economic functions. Fishery resources of mangrove forests are very productive, both quantitatively and qualitatively, because the mangrove forests act as the natural habitat (spawning, nursery and feeding grounds) for various species of fish, shrimps and crabs, as well as a source of germplasm and genetic pool. Mangrove forests also provide valuable ecosystem services to coastal communities, tourist attractions, nature conservation, education and research. However, these ecosystems are fragile because it is very sensitive to environmental changes, usually because anthropogenic influences; therefore, it is difficult to be restored. In addition, these ecosystems are so openly accessible that easily exploited by humans; this can reduce its quality and quantity. Local communities who use mangrove forests and their resources may have considerable botanical and ecological knowledge about their forests. Silvofishery techniques in aquaculture are very suitable for community-based mangrove forests conservation efforts. Silvofishery is an integrated model that considers both economically benefit and conservation.
\end{abstract}

Key words: mangrove conservation, sustainable fisheries, community-based

\section{INTRODUCTION}

The mangrove forests are a type of salt tolerant vegetation, living in tidal zones in tropical and subtropical coastal areas with unique ecosystem that have a strategic function as a connector and counterweight of terrestrial and marine ecosystems (Pramudji 2003; Wibowo and Handayani 2006; Fatoyinbo et al. 2008; Zamroni and Rohyani 2008; Strauch et al. 2012). Mangrove forest ecosystems are very complex because it occurs in a mutual relationship between animals, plants and the environment (Pramudji 2003). Mangrove forests are a productive ecosystem and has complex functions, such as physical functions, biological functions (spawning ground, nursery ground, feeding ground, as well as a source of germplasm and genetic pool) and socio-economic functions (Wibowo and Handayani 2006; Walters et al. 2008).

Fishery resources of mangrove forests are very productive, both quantitatively and qualitatively, because the mangrove forests act as the natural habitat of various species of fish and shrimps. Mangrove forests support local fisheries and provide a natural nursery habitat and marine productivity that support a wider commercial fisheries (Walters et al. 2008). The existence of diverse mangrove species will support the diversity and abundance of aquatic biota such as fish and shrimps. The abundance of mangrove species closely related to the biotic processes such as succession species or competition and abiotic factors, such as nutrient availability, water quality, soil composition and tidal inundation (Strauch et al. 2012).

Mangrove forest ecosystems are complex and dynamic, but unstable because it is easily degraded due to interference and difficult to be restored (Anwar and Gunawan 2006). The main cause of degradation of mangrove forests in the world is due to anthropogenic influences. As well as the main cause of deforestation of mangrove forests in South Asia is due to conversion of forest to agriculture, shrimp farms, and residential construction (Giri et al. 2014). Development of agricultural lands and shrimp farms in coastal areas caused the loss of mangrove forests in South and Southeast Asia by $90 \%$ from total 1.9 million ha (Gupta and Shaw 2013).

Mangrove forest conservation needed to improve the outcome of sustainable fisheries. Biological conservation purposes, such as mangrove forests, are studying the impact from human activities on the species, communities and ecosystems, as well as approach efforts to avoid the extinction of species and restore endangered species to ecosystem that still function (Primack et al. 1998). Mangrove forest conservation should involve local communities because they require the existence of sustainable mangrove forest to fulfill their needs and they also have local wisdom that has been tested for so long in maintaining the sustainability of mangrove forests.

This article discusses the conservation of local community-based mangrove forests. Conservation of 
mangrove forests will increase the productivity of fisheries in the region which is crucial to improve the economy of local communities. This article contains a collaboration of various literature and the results of relevant research to reveal the facts that exist.

\section{RESULT AND DISCUSSION}

\section{Degradation of Mangrove Forests}

Mangrove forests have physical, biological and socio-economic functions. However, mangrove forest ecosystems are open access so easily exploited by humans and reduce their quality and quantity (Wibowo and Handayani 2006). In addition, the overlapping interests of the mangrove forest resources would create ambiguity ownership; it will make difficult to manage and lead to conflict (Walters et al. 2008). Various activities undertaken in the area of mangrove forests has increased degradation. The main cause of mangrove forest degradations is due to human activity (anthropogenic influences).

The main cause of deforestation of mangroves in South Asia is conversion of forests, for example, agriculture, shrimp farms, and residential construction; excessive use of the mangrove forest resources (animals and plants); pollution; a decrease in the availability of fresh water; flooding; reduced sedimentation; coastal erosion, and disturbance of tropical storms and tsunamis (Giri et al. 2014). Meanwhile, degradation of mangrove forests in Southeast Asia caused by conversion to agriculture and aquaculture (Laulikitnont 2014). The main cause mangrove forests degradation in 10 countries, both in highly developed countries (Australia, Brazil, Mexico and USA) and Less Developed Countries (India, South Africa, Kenya, Kiribati, Indonesia and Sri Lanka) is development (Mukherjee et al. 2014).

Shrimp farming that growing rapidly in the Mekong Delta province of Tra Vinh has a negative impact on the loss of mangrove forests. Loss of mangrove forests in the region reached $50 \%$ during the period 1965 to 2001 (Thu and Populus 2007). Mangrove forest in southern Thailand is only a secondary forest as a result of the use of wood by the industry and the population for fuel, charcoal, as well as shrimp farming, and mining of tin (Komiyama 2014). Likewise, the mangrove forests in Madagascar lost approximately 7,659 ha $(23.7 \%)$ due to increased extraction for charcoal and wood, as well as conversion to agriculture and aquaculture over the period 1990 to 2010 (Jones et al. 2014).

Conditions of mangrove forests in Indonesia today is quite alarming. It is due to the excessive use of mangrove forests and less consideration of environment carrying capacity and sustainability of the resource coastal areas. Degradation and loss of mangrove forests in Indonesia caused by several key factors, namely the conversion of mangrove forests into farms fisheries, oil palm plantations, agriculture, salt ponds, settlements, industries, logging (legal logging and illegal logging), mining and natural disasters (Ilman et al. 2011).

According to the Ministry of Forestry, Indonesia had mangrove forests around 4.25 million ha in 1982. After fourteen years later (1996), Indonesia's remaining mangrove forests around 3.53 million ha (Raymond et al. 2010). Directorate General of Land Rehabilitation and Social Forestry (Ditjen RLPS) Ministry of Forestry reported that Indonesia still has mangrove forests about 7.7 million ha in 2000 , with details of $30.7 \%$ good condition, $27.4 \%$ minor damage and $41.9 \%$ severely damaged. According to the Coordinating Agency for Surveys and Mapping (Bakosurtanal) that Indonesia's remaining mangrove forests estimated at 3.2 million ha in 2009 (Ilman et al. 2011; Kusmana 2014). It showed that approximately 9 years, more than 4.5 million ha of Indonesia's mangrove forests lost.

Mangrove forest on the east coast of North Sumatra there were still about 103,415 ha in 1977, but in 2006 its remaining stays 41,700 ha. The main cause of mangrove forest loss were logging and land conversion for farms, plantations and agriculture (Onrizal 2010). A decrease in the quality and quantity of mangrove forests resulted alarming impact, such as increased abrasion, decreased in fishing income, increased sea water intrusion and increased incidence of malaria (Onrizal and Kusmana 2008). Moreover, the physical infrastructure developments have had several negative impacts ranging from water quality deterioration and dynamic shifts in mangrove vegetation to reduced fish production in the vicinity (Satyanarayana et al. 2013).

\section{Community-Based Mangrove Forests Conservation}

Mangroves support local fisheries and also provide critical nursery habitat as well as marine productivity which support wider commercial fisheries; they also provide valuable ecosystem services that benefit coastal communities, including coastal land stabilization and storm protection (Walters et al. 2008). Local communities require the existence of sustainable mangrove forest resources to fulfill their needs and get the benefit of the ecosystem services. Similarly, local communities on the Galle-Unawatuna area (Sri Lanka) used mangroves to a greater extent for fishery products, fuelwood and edible plants, than for house/boat construction material, medicinal and other non-timber forest products (Satyanarayana et al. 2013).

Local communities have local wisdom that proven to conserve their region. Local communities who use mangroves and their resources may have considerable botanical and ecological knowledge about their forests (Walters et al. 2008). Studies of community-based conservation of mangrove forests in the world described below.

The strategy in the management of mangrove forests in Sinjai done by empowering people, improving education to the community, involving the public in the preparation of the planning and implementation of mangrove management, government and public support mangrove management, as well as an increase in mangrove planting around the coast (Patang 2012). Mangrove restoration dependent on site conditions and emphasizes community involvement and ecosystem level monitoring as integral components of restoration projects (Bosire et al. 2008).

The study in Trang Province, Thailand shown that mangrove forests can be managed and conserved by 
local communities. Moreover, the condition of community-managed mangrove forests was superior to that managed by the state. Establishment of a successful community mangrove forest in the face of conflict with powerful outside interests was a major achievement in Trang, and future research should be directed to clarify how, when, and where community management is a viable alternative to state-run mangrove management (Sudtongkong and Webb 2008).

National and local scenarios needed to sustain mangrove forests in Tanzania. This problem can be addressed through research and analysis of policy and institutional frameworks, for example indigenous knowledge and traditional management systems need to be understood and evaluated for an efficient incorporation (Mangora 2011). Meanwhile, Mangrove rehabilitation programs in Bang La, Vietnam have been successfully conducted by community-based forest management in cooperation with local authorities (Dat and Yoshino 2013).

The linkages of mangrove ecosystem services with local livelihoods are direct and tangible. It is therefore possible needed to develop strong local support for sustainable management of mangrove forests. Actual issues at this time on Reducing Emissions from Deforestation and Degradation (REDD) and payment for ecosystem services provide ample scope for development of sustainable livelihood options for local communities from the conservation of critical ecosystems such as mangroves (Badola et al. 2012). The local communities participation in resource management and direct tangible benefits from conservation are of prime importance (Badola et al. 2012).

Community-Based Mangrove Management (CBMM) has become an alternative for sustainably managing the ecological of mangrove forests. Proper disbursement of accrued benefits among local community irrespective of their socio-cultural status is also a major concern (Datta et al. 2012). Indonesia has carried out CBMM since the 1980s with a high level of success. NGOs and research organizations promoted CBMM first and government initiatives came later (Datta et al. 2012).

Customary management $(\mathrm{CM})$ and integrated coastal management (ICM) are best paradigm in ecosystembased management (EBM) that should be integrated into existing systems. The cultural and institutional context of the CM as well as the experience, technical skills, and the legal basis servei that CM programs are logical platforms from the which to build EBM programs (Aswani et al. 2012).

The conservation strategies of mangrove forests involving local communities seen as more effective than simply involve the government (Erwiantono 2006). There are three factors of public participation in decision-making mangrove forest management, namely management factors, knowledge factors and attitude factors (Raymond et al. 2010). The government has to provide technical, educational and financial support for local community organizations joining in management activities of mangrove forests (Dat and Yoshino 2013).

\section{Silvofishery For Sustainable Fisheries}

Mangrove restoration has a big potential to increase the mangrove resources, provide employment to local communities, protect tropical coastlines and also to enhance biodiversity and fisheries productivity (Kairo et al. 2001). The existence of mangrove forests is very important to increase fishery production because mangrove forests provide habitat for aquatic biota, including fish, shrimps and crabs. Mangrove forests are protective coastal areas from a variety of disorders, as well as provide habitat for over 1,300 species of animals and one of the most productive ecosystems (Fatoyinbo et al. 2008).

Mangrove forest ecosystems are very complex because it occurs symbiotic mutualism between animals, plants and their environment (Pramudji 2003). Soft substrates provide a habitat for a variety of benthos, while the spaces between the roots provide habitat for motile animals such as fish, shrimps and crabs (Nagelkerken et al. 2008).

Silvofishery techniques in aquaculture are very suitable for mangrove forest conservation efforts. Silvofishery is a form of local wisdom in sustainable coastal aquaculture through low input and integrated approach to maintaining the integrity and sustainability of mangrove forests (Triyanto et al. 2012). Management and development of mangrove forest ecosystems, including for silvofishery activities, should be based on the principle of sustainability, benefits and integration (Wibowo and Handayani 2006). Management of coastal resources for aquaculture need to consider its sustainability by the application of silvofishery system (Budihastuti 2013). Silvofishery is an integrated model that considers both economically benefit and conservation (Hidayatullah and Umroni 2013). Studies of Silvofishery and their benefits described below.

The existence of mangrove forest around the ponds can improve pond fertility due to detritus as a food source of fish and shrimps. In addition, fallen mangrove leaves suspected to contain alelopati compounds to reduce disease in fish ponds (Wibowo and Handayani 2006). Litter decomposition is a process of nutrient transformation involving aquatic organisms (Budihastuti et al. 2012). As happened in Konawe District, after only two years from planted with mangrove seedling there is a noticeable improvement of mangrove habitats in front of the villages as the productivity of marine life has increased. The fishermen report that they could catch fish and other economic marine biota again near to their villages (Hamundu and Manan 2004).

Silvofishery is a cultivation system that can improve the productivity of tiger shrimp (Penaeus monodon) (Budihastuti 2013). Besides that, silvofishery provide a good influence on the improvement of water quality (Hidayatullah and Umroni 2013). The presence of mangrove in the ponds area is able to improve the oxygen content and $\mathrm{pH}$ of pond water and able to bind nitrates which prevent the pond water from pollution (Purwiyanto and Agustriani 2014).

Aquatic biota such as fish and shrimps, require the presence of mangroves for their survival because mangroves have an important role to maintain of aquatic fertility and neutralize waste waters. For example, three 
of mangrove species (Avicennia germinans, Laguncularia racemosa, and Rhizophora mangle) could be used in a closed silvofishery systems for the biological removal of ammonium, nitrite, nitrate, and phosphate (De-León-Herrera et al. 2015). Revitalization of non productive fishponds at Mahakam Delta with silvofishery system was conducted by government and local community, applied with three types of bakau planting site, i.e.: permanent flooded, periodically flooded and not flooded site (Suwarto et al. 2015).

Economic valuations of mangrove ecosystem in Samataring and Tongketongke sub-districts, South Sulawesi covers direct use value of $R p 48,303,875$,- ha1 year-1, indirect use value of $\operatorname{Rp} 3,338,650$,- ha- 1 year1 , alternative use value of $\mathrm{Rp} 142,500$,- ha- 1 year-1, and existence use value of $\mathrm{Rp} 3,917,722,-$ ha-1 year-1 (Sambu 2014). Meanwhile, correlation between mangrove ecosystem direct benefit value and increased coastal catch produce in Sinjai District, Sulawesi, Indonesia showed positively correlate and result in an equation of $\mathrm{y}=0.485 \mathrm{x}-0.347$ with $\mathrm{R} 2=0.99$ (Haris et al. 2013).

One ha of fish farm on natural mangrove forest will produce fish and shrimps as much as $287 \mathrm{~kg} / \mathrm{year}$, but the loss of one ha of mangrove forests resulted in loss of fish and shrimps of $480 \mathrm{~kg} /$ year (Anwar and Gunawan 2006). Meanwhile, mangrove forest area of 146 ha in coastal area of Gending subdistrict, Probolinggo provide benefit value to the fisheries production amounting Rp 3,478,802,500,-/year (Harahab et al. 2009). Restoration of mangrove forests by local communities in TongkeTongke, South Sulawesi since 1986 showed an increase in the potential of the fishery; they prevent coastal erosion and flooding as well as found 27 species of fish, 4 species of shrimps, at least 8 species of gastropods and 8 species of bivalves (Gunarto 2004).

\section{CONCLUSIONS}

Mangrove forests are a productive ecosystem and they have complex functions, such as physical functions, biological functions and socio-economic functions. Fishery resources of mangrove forests are very productive because the mangrove forests act as the natural habitat for various species of fish, shrimps and crabs. Local communities who use mangrove forests and their resources may have considerable botanical and ecological knowledge about their forests. Silvofishery techniques in aquaculture are very suitable for community-based mangrove forests conservation efforts. Silvofishery is an integrated model that considers both economically benefit and conservation; it is a model of sustainable fisheries.

\section{REFERENCES}

Anwar C, Gunawan H. 2006. Peranan ekologis dan sosial ekonomis hutan mangrove dalam mendukung pembangunan wilayah pesisir. Proceedings of Exposure Research Results. p 23-34.
Aswani S, Christie P, Muthiga NA, Mahon R, Primavera JH, Cramer LA, Barbier EB, Granek EF, Kennedy CJ, Wolanski E, Hacker S. 2012. The way forward with ecosystem-based management in tropical contexts: reconciling with existing management systems. Marine Policy 36: 1-10.

Badola R, Barthwal S, Hussain SA. 2012. Attitudes of local communities towards conservation of mangrove forests: a case study from the east coast of India. Estuarine, Coastal and Shelf Science 96(2012): 188-96.

Bosire JO, Guebas FD, Walton M, Crona BI, Lewis RR, Field C, Kairo JG, Koedam N. 2008. Functionality of restored mangroves: a review. Aquatic Botany 89: 251-59.

Budihastuti R, Anggoro S, Saputra SW. 2012. The application of silvofishery on tilapia (Oreochromis niloticus) and milkfish (Chanos chanos) fattening within mangrove ecosystem of the northern coastal area of Semarang City. Journal of Coastal Development 16(1): 89-93.

Budihastuti R. 2013. Pengaruh penerapan wanamina terhadap kualitas lingkungan tambak dan pertumbuhan udang di Kota Semarang. Proceedings of National Seminar on Management of Natural Resources and Environment p 374-77.

Dat PT, Yoshino K. 2013. Comparing mangrove forest management in Hai Phong City, Vietnam towards sustainable aquaculture. Procedia Environmental Sciences 17: 109-18.

Datta D, Chattopadhyay RN, Guha P. 2012. Community based mangrove management: a review on status and sustainability. Journal of Environmental Management 107(2012): 84-95.

De-León-Herrera R, Flores-Verdugo F, Flores-deSantiago F, González-Farías F. 2015. Nutrient removal in a closed silvofishery system using three mangrove species (Avicennia germinans, Laguncularia racemosa, and Rhizophora mangle). Marine Pollution Bulletin 91(2015): 243-248.

Erwiantono. 2006. The community participation in mangrove ecosystem management in Pangpang Bay, Muncar - Banyuwangi. Jurnal Ekonomi Pembangunan dan Perencanaan (EPP) 3(1): 4450.

Fatoyinbo TE, Simard M, Allen RAW, Shugart HH. 2008. Landscape-scale extent, height, biomass, and carbon estimation of Mozambique's mangrove forests with landsat ETM+ and shuttle radar topography mission elevation data. Journal of Geophysical Research 113: 113.

Fatoyinbo TE, Simard M, Allen RAW, Shugart HH. 2008. Landscape-scale extent, height, biomass, and carbon estimation of Mozambique's mangrove forests with landsat ETM+ and shuttle radar topography mission elevation data. Journal of Geophysical Research 113: 113. 
Giri C, Long J, Abbas S, Murali RM, Qamer FM, Pengre B, Thau D. 2014. Distribution and dynamic of mangrove forests of South Asia. Journal of Environmental Management 30:111.

Gunarto. 2004. Mangrove conservation for supporting biotic resources of coastal fisheries. Jurnal Litbang Pertanian 23(1): 15-21.

Gupta RD, Shaw R. 2013. Cumulative impacts of human interventions and climate change on mangrove ecosystems of South and Southeast Asia: an overview. Journal of Ecosystems 2013:1-15.

Hamundu M, Manan A. 2004. Extention and communication in the integrated management strategy for the sustainable development of Konawe Coastal, area Southeast Sulawesi, Indonesia. Manusia dan Lingkungan 11(2): 96102.

Harahab N, Riniwati H, Mahmudi M, Sambah A. 2009. Caracteristic mangrove forestry and the benefit value for fisheries product In coastal zone Gending Probolinggo Regency. Jurnal IlmuIlmu Hayati (Life Sciences) 21(1): 44-9.

Haris A, Damar A, Bengen D, Yulianda F. 2013. Correlation between mangrove and aquaculture production: case study in Sinjai District, Sulawesi, Indonesia. International Journal of Aquaculture 3(14): 73-78.

Hidayatullah M, Umroni A. 2013. Growth of mangrove (Rhizophora mucronata Lamk) and productivity of silvofishery units at Kupang Regency. Jurnal Penelitian Hutan dan Konservasi Alam 10(3): 315-25.

Ilman M, Wibisono ITC, Suryadiputra INM. 2011. State of the Art Information on Mangrove Ecosystems in Indonesia. Bogor: Wetlands International-Indonesia Programme.

Jones TG, Ratsimba HR, Ravaoarinorotsihoarana L, Cripps G, Bey A. 2014. Ecological variability and carbon stock estimates of mangrove ecosystems in Northwestern Madagascar. Forests 5: 177-205.

Kairo JG, Dahdouh-Guebas F, Bosire J, Koedam N. 2001. Restoration and management of mangrove systems - a lesson for and from the East African region. South African Journal of Botany 67(2001): 383-89.

Komiyama A. 2014. Conservation of mangrove ecosystems through the eyes of a production ecologist. Agricultural Science 2: 11-20.

Kusmana C. 2014. Distribution and current status of mangrove forest in Indonesia. In: Mangrove Ecosystems of Asia: Status, Challenges and Management Strategies. Edited by Hanum F, Latiff A, Hakeem KR, Ozturk M. New York: Springer Science+Business Media 37-60.

Laulikitnont P. 2014. Evaluation of Mangrove Ecosystem Restoration Success in Southeast Asia. Master's Projects. California: University of San Francisco.

Mangora MM. 2011. Poverty and institutional management stand-off: a restoration and conservation dilemma for mangrove forests of Tanzania. Wetlands Ecol Manage 19: 533-43.

Mukherjee N, Sutherland WJ, Khan MNI, Berger U, Schmitz N, Dahdouh-Guebas F., Koedam, N. 2014. Using expert knowledge and modeling to define mangrove composition, functioning, and threats and estimate time frame for recovery. Ecology and Evolution 4(11): 2247-62.

Nagelkerken I, Blaber SJM, Bouillon S, Green P, Haywood M, Kirton LG, Meynecke J-O, Pawlik J, Penrose HM, Sasekumar A, Somerfield. 2008. The habitat of mangrove for terestrial and marine fauna: a review. Aquatic Botany 89(2008): 155-85.

Onrizal dan Kusmana, C. 2008. Ecological study on mangrove forest in East Coast of North Sumatra. Biodiversitas 9(1): 25-9.

Onrizal. 2010. Land-cover change of mangrove forests at eastern coast of North Sumatra in Period 1977 to 2006. Jurnal Biologi Indonesia 6(2): 163-72.

Patang. 2012. Mangrove forest management strategy analysis (cases in the Tongke-Tongke Village, Sinjai Regency). Jurnal Agrisistem 8(2): 10009.

Pramudji. 2003. Flora diversity of mangrove forest in the coastal zone of Mandar Bay Polewali, South Sulawesi Province: a preliminary study. Biota 8(3): 135-42.

Primack RB, Supriatna J, Indrawan M, Kramadibrata P. 1998. Biologi Konservasi. Jakarta: Yayasan Obar Indonesia.

Purwiyanto AIS, Agustriani F. 2014. Effect of silvofishery on ponds nutrient levels. Ilmu Kelautan 19(2): 81:7.

Raymond GP, Harahap N, Soemarno. 2010. Community based management of mangrove forest in the Gending Subdistrict, Probolinggo. Jurnal Agritek 18(2): 185-200.

Sambu AH. 2014. Analysis of characteristics of and use value of mangrove ecosystem (case study in Samataring and Tongketongke Sub-Districts, Sinjai Regency). Journal of Environment and Ecology 5(2): 222-233.

Satyanarayana B, Mulder S, Jayatissa LP, DahdouhGuebas F. 2013. Are the mangroves in the Galle-Unawatuna area (Sri Lanka) at risk? A social-ecological approach involving local stakeholders for a better conservation policy. Ocean and Coastal Management 71(2013): 225-37.

Strauch AM, Cohen S, Ellmore GS. 2012. Environmental influences on the distribution of mangroves on Bahamas Island. Journal of Wetlands Ecology 6:16-24.

Sudtongkong C, Webb EL. 2008. Outcomes of state- vs. community-based mangrove management in Southern Thailand. Ecology and Society 13(2): $1-23$.

Suwarto, Lahjie AM, Ruchaemi A, Simorangkir, BDAS, Mulyadi F. 2015. Ecological aspect of non productive fishponds at Mahakam Delta area: revilatization with silvofishery system. 
Global Journal of Agricultural Research 3(1): 27-37.

Thu PM, Populus J. 2007. Status and changes of mangrove forest in Mekong Delta: case study in Tra Vinh, Vietnam. Estuarine, Coastal and Shelf Science 71: 98-109.

Triyanto, Wijaya NI, Widiyanto T, Yuniarti I, Setiawan F, Lestari FS. 2012. Pengembangan silvofishery kepiting bakau (Scylla serrata) dalam pemanfaatan kawasan mangrove di Kabupaten Berau, Kalimantan Timur. Proceedings of the National Seminar of Limnology VI p 739-51.
Wibowo K, Handayani T. 2006. Pelestarian hutan mangrove melalui pendekatan mina hutan (Silvofishery). Jurnal Teknik Lingkungan 7(3): 227-33.

Walters BB, Ronnback P, Kovacs JM, Crona B, Hussain SA, Badola R, Primavera JH, Barbier E, Dahdouh-Guebas F. 2008. Ethnobiology, socio-economics and management of mangrove forests: a review. Aquatic Botany 89: 220-236.

Zamroni Y, Rohyani IS. 2008. Litterfall production of mangrove forest in the beach waters of Sepi Bay, West Lombok. Biodiversitas 9(4): 284-87. 